\title{
Facilitating the Development of the Autonomous Language Learner Using Online Virtual Learning Environments
}

\author{
Mark Brooke \\ Hong Kong Institute of Education, Hong Kong SAR, China
}

\begin{abstract}
This paper argues that if used correctly, computer-mediated courseware (CMC), in the form of an online Virtual Learning Environment (VLE) such as Blackboard or Moodle, has the potential to offer adult learners in university settings an optimal autonomy-supportive environment for learning English as a second language at a distance. The paper firstly considers how to promote learner autonomy through offering participants choices during the initial stages of a course through a negotiated syllabus. It then divides the language learning process into metacognitive and cognitive linguistic capacities and provides examples of strategies to increase autonomy in these spheres. Autonomy with regard to metacognitive linguistic capacities can be developed first by the multimodal aspect of $\mathrm{CMC}$, in particular, the unprecedented access to resources, second, through the array of mediums to select in the creation and submission of assignments and third, through the notion of 'dissemination' (Mayes, 2002), which allows for 'vicarious learning' (Bandura, 1986). Autonomy with regard to cognitive linguistic capacities can be promoted through goal-oriented participant interaction on spoken and written forums on the platform, followed by consciousness-raising language activities guiding students to notice patterns in the language. In conclusion, it is suggested that a VLE might lead to optimum learning through the facilitation of a state of 'flow' or 'autotelic' activity, a concept closely related to autonomy and intrinsic motivation.
\end{abstract}

Index Terms - computer-mediated courseware, virtual learning environment, autonomy \& self determination theory, metacognitive and cognitive linguistic capacities

\section{Defining Autonomy}

The term, 'autonomy' was first introduced to the field of adult language learning by Holec in the early 1970s (see CRAPEL: Centre de Recherche Appliquée Pour l'Enseignement des Langues in Nancy and its researchers, e.g., Riley, 1986, 1997). Its catalyst was the political climate of France in the late sixties, which reached its climax in 'Mai '68', and saw the growth of liberal morality in particular in the spheres of equality, sexual liberation and human rights. As Jane (1977, cited by Holec 1981, p.1) postulates, rather than 'products', citizens become 'producers of society'. Individuals were encouraged to be responsible and active in positively shaping their own lives and in doing so, aware that they were contributing to a change in the life of others. In the words of Collins \& Hammond (1991):

'Autonomy begins with the assumption that the ultimate purpose of education is the betterment of society, and that critical awareness and social action to promote emancipation are desirable results of any educational intervention' (p.13 cited in Reinders, 2000, p. 4).

The origin of autonomy in education is therefore inextricably linked with notions of interpersonal relations; social responsibility and activity; belief in communitarian values; and freedom of choice and expression.

\section{Autonomy and Language Learning}

These emerging ideas were in direct opposition to the dominant ontological and epistemological notions inherent in the educational practices of the fifties and early sixties in Western Europe and America. The prominent Objectivist or Positivist paradigm assumed that knowledge is external to the knower and can be transferred from one person to another in a static way emphasising 'learning as an incremental mathematically-facilitated process' (Felix, 2002, p. 6), i.e., a student would first learn the use of I + verb, then he + verb, followed by you, they and so on or a student would first learn the present simple tense, second, the present continuous and so on. However, as Larsen and Freeman (cited in Thornbury (2001) argue: 37).

'Learning linguistic items is not a linear process - learners do not master one item and then move on to another' (p.

The foreign language learning methodology based on this linear process was led by approaches such as the Audiolingual Method (see Fries, 1945, and Fries \& Fries, 1961 and appendix 1 for an example of the structure of a typical lesson of this method). The teacher's role in the classroom was of paramount importance as he or she delivered a pre-conceived syllabus and the supposed appropriate methodology with which to implement it (predominantly a question-response interaction, also known as the IRF sequence: initiation (tutor) - response (student) - feedback (tutor). 
The students, on the other hand, were extremely passive and a minimum of peer to peer interaction took place. Their role was to remember and reproduce the knowledge transmitted by the teacher (Schank and Jona, 1991, call this the 'sponge method'). Based on Behavioural Psychology (see Thorndike, 1913 and Skinner, 1953), these methodologies propounded that learning could only take place if it was followed by rewards. According to this school, learning is dependent on three crucial elements: a stimulus, which serves to elicit behaviour; a response triggered by a stimulus; and reinforcement, which reveals if the response was appropriate (followed by positive reinforcement) or inappropriate (followed by negative reinforcement). In other words, if learners responded well to a question or prompt by the teacher, they would be praised or receive a congratulatory token. This praise would encourage the learner to reenact this response and even increase the reoccurrence and strength of it.

Researchers, such as Harlow (1950) and Hunt (1965, 1971) opposed Behaviourism as they revealed that even monkeys had curiosity-related behaviours, such as exploration, which were performed purely for the pleasure of the behaviours themselves, and not merely due to the desire for rewards. In addition, Chomsky (1966) rejected these learning theories offering one based on the creativity of the human mind: 'transformational grammar'. He writes:

'Language is not a habit structure. Ordinary linguistic behaviour characteristically involves innovation, formation of new sentences and patterns in accordance with rules of great abstractness and intricacy'. (1966, p. 153)

Chomsky (1966) argued that each individual uses language uniquely. If segments or patterns of a language were merely absorbed and regurgitated, why did different individuals using the same words, construct them in different ways to form unique sentences? Another view to learning theories was needed as notions of curiosity, interest and creativity could not be accommodated by the drive theory of Behaviourism.

The Objectivist (Positivist) paradigm, Behaviourist assumptions and Audiolingual Methodology, related to these, are in direct opposition to the ontological and epistemological underpinnings of the Constructivist Paradigm as well as Self Determinism Theory (SDT: http://www.psych.rochester.edu/SDT/theory.html), a movement which stresses the importance of autonomy. Deci and Ryan (1985, 1991, 1995 and 2000) outline the fundamental dichotomy between these two broad theoretical orientations to motivation: one is mechanistic (Behaviorist theory); the other, organismic (Self Determinism Theory or SDT):

'Mechanistic theories tend to view the human organism as passive, that is as being pushed around by the interaction of physiological drives and environmental stimuli, whereas organismic theories tend to view the organism as active, that is, as being volitional and initiating behaviours'. (Deci \& Ryan 1985, pp. 3-4)

As Piaget declares:

'The nature of life is always to overtake itself.'

(Cited in Deci and Ryan, 1991, p. 239)

Development and progress are among the fundamental cruxes of existence. In addition, Constructivists argue that individuals build their own reality based on a unique set of experiences, beliefs and personal abilities. Consequently, the onus is on the subjective processes of understanding and learning about one's environment. Thus, as Evans and Nation (1992) state, information can be transmitted but knowledge solely induced. An item will be learnt when a learner is ready to do so and what the learner learns may not necessarily be what the teacher aspires to teach i.e., the lesson's target language. This is wholly at odds with Audiolingualism.

SDT, in addition, propounds that rewards, in direct contrast to Behaviorist assumptions, hinder learning. Such external influences, according to DeCharms, (in Deci and Ryan, 2000: 8; see also Amabile, DeJong and Lepper, 1976) cause a shift in a person's 'perceived locus of causality' (PLOC) and thus a movement from intrinsic to extrinsic perceptions of control. As studies by Deci and others (e.g., Lepper et al., 1973) have suggested, the behaviour increasingly moves from internally to externally-motivated and individuals no longer feel 'causality pleasure' (Nuttin, 1973) as their actions are progressively other-initiated.

The need to learn and evolve without feelings of being externally (extrinsically) controlled is inherent in living organisms and this is evident in the basic, innate, psychological need for autonomy. Two others: competence and relatedness also underpin, though to a lesser extent, the human psyche. According to Deci \& Ryan (1991):

'Autonomy refers to being self-initiating and self-regulating of one's own actions'. (p. 327).

This, along with competence and relatedness are life-span tendencies and together form an organismic dialectical meta-theory which at its core propounds that a person's natural state is to be intrinsically motivated:

'Intrinsic motivation [in contrast to extrinsic] is in evidence whenever students' natural curiosity and interest energise their learning'. (Deci and Ryan: 1985, p. 245)

In its truest form, the learning experience is its own reward. Research (Deci and Ryan, 2000, p. 70) has shown that contexts striving to support the optimal satisfaction of these innate needs, in particular perceived feelings of autonomy, promote intrinsically motivated individuals. In contrast, when these are thwarted, there is diminished motivation and well-being (Deci and Ryan, 2000). In addition, it is essential to strive to maintain intrinsically motivated behaviours as this natural tendency does not operate automatically but 'requires nutriments to function effectively' (Deci and Ryan, 2000, p. 238.). As a result, Cognitive Evaluation Theory (CET) is presented by Deci and Ryan (1985) as a sub-theory within SDT, with the aim of specifying environmental and social factors that explain variability in intrinsic motivation, i.e., degrees to which these facilitate versus undermine intrinsic motivation. As Deci and Ryan demonstrate, there are not solely two factors of activity regulation, or degrees of intentional behaviour/ relative autonomy, i.e. self-regulated or 
other-regulated, but at least four types, and the contextual factors that facilitate or hinder the regulation of these behaviors, based on individuals' or groups' perceptions of extrinsic or externally-originated environmental forces. Deci and Ryan (1985) present this as the Organismic Integration Theory (OIT).

The following is the taxonomy of OIT, moving from externally to internally motivating forces: external; introjected; identified; and integrated regulation. 'External regulation' is behaviour initiated by another (a reward, threat, a desire to be praised). This is the least self-determined form of external motivation. The second is 'introjected regulation' which 'involves internalised rules or demands that pressure one to behave and are buttressed with threatened sanctions (e.g. guilt) or promised rewards (e.g. self-aggrandizement)' (Deci et al. 1991: 329). Although another does not necessarily need to be involved for this form, it is still not considered as self-determined, or part of the integrated self as it is not a choice based on free will. An example given by Deci and Ryan is a boy who turns up at school punctually because he would feel bad if he were late. The third type of extrinsic motivation is 'identified regulation'. In this case, the individual is interested in an activity and has identified with it. The behaviour is 'more fully a part of the self, so the person does the activity more willingly' (Deci et al. 1991, p. 330). Internally stimulated feelings such as choice and volition accompany a particular activity. Deci et al (1991, p. 330) note that this might be a student whose goal is to become 'good at Maths' but this is not undertaken through intrinsic interest but through egocentric desire. Finally, the fourth category is 'integrated regulation'. This is 'the most developmentally advanced form of extrinsic motivation' (Deci et al. 1991, p. 330). It differs from intrinsic motivation because while an activity chosen is personally valued, it is related to an important outcome whereas for the latter, the activity is chosen purely from interest and enjoyment itself.

Offering choices to learners, promoting the integration of external forces in the environment is therefore of paramount importance. As Deci \& Ryan state:

'Events such as choice and positive feedback that facilitate self determined competence have an informational significance and were found to enhance intrinsic motivation.' (1985, p. 85)

Deci and Ryan (2000, p. 73) argue that studies in education reveal that the more extrinsic forces are integrated, the more they are associated with deeper engagement (Connell and Wellborn, 1991, cited in Deci and Ryan, 2000, p. 73), better performance (Miserandino, 1996: ibid), lower dropout (Vallerand and Bissonnette, 1992, Ibid), higher quality learning (Grolnick and Ryan, 1987, ibid), and better teacher ratings (Hayamizu, 1997, ibid). The notion of integration is thus of paramount importance for education, in this case, with regard to online adult distance courses in the field of TESOL. In concrete terms, and with reference to researchers on autonomy in the TESOL community (Aoki, 1999; Benson 2000, 2001; Benson and Toogood, 2001; Bergen 1990, cited in Dam, 1995; Dickinson, 1987; Holec, 1981; Little, 1991), the ideal is to promote an environment that can offer choice leading to self determining actions hence building learner motivation in deciding what, why and how to learn English. It could be argued that this is particularly relevant to distance learning to bridge the physical, temporal and geographical divides which segregate learners from the institution at which they are enrolled and from the participants and tutors on the course provided.

\section{Using TeChNOlogy to NuRtuRE AutonOmOUs LANGUAGE LEARNING}

\section{A. Developing Metacognitive Linguistic Capacities}

Murphy (2005) argues that only with metacognitive awareness can students decide which learning strategies and resources they prefer, and if they have preferences, to what extent these are to be used. As O'Malley et al (1985) note:

'Students without metacognitive approaches are essentially learners without direction and ability to review their progress, accomplishments and future learning directions' (p. 24).

Metacognition in second language learning is, in part, the knowledge of one's learning styles and preferences and the efficient use of this self-awareness to self-regulate these processes. According to Hedge (2000), this predominantly includes the planning, self-monitoring, and evaluation of one's own language learning. In SDT theory, having these choices require a learner to develop self-initiating and self regulating skills.

In a tertiary institution, it is evident that an online course, offered at a distance, consists of pre-conceived intended learning outcomes and evaluation criteria, and in this way is impersonal, and to a large extent extrinsically motivating as learners have no say in the content or delivery of the programme. However, a significant impact on the development of learner autonomy can be made at the outset by, as Clarke (1991) argues, working towards a 'negotiated syllabus':

'Learners might be allowed a degree of choice and self-expression, unavailable in most existing syllabus types' (pp, 13-28).

Influenced by Dewey's 'Experience and Education' (1938), Moore's theory (1993) of 'Transactional Distance' describes the dynamic relationship that exists between dialogue and structure in a distance programme. Dialogue is communicative interaction. Structure refers to the instructional programme. The 'transaction' is a negotiation between teacher, students and course obligations. Structural change depends on striking a balance between needs and formal requirements. As its title suggests, this theory aims at reducing the divides. A contemporary VLE such as Blackboard or Moodle, because of its multimodal nature, provides this unprecedented infrastructure, allowing syllabus negotiation (see Steeples et al, 2007; Bangeni and Nel, 2007).

By increasing students' freedom to choose a variety of technological connectivities and social interactivities between teachers and learners and learners themselves, choices in the medium of communication can be given and promoted. Milton (2007) http://www.cs.ust.hk/gong, for example, has developed "Gong", a discussion forum with a voice- 
recording feature, in addition to a text-chat area, that can be used synchronously or asynchronously. Learners can also be given choices regarding the delivery of teaching courseware as well as the submittal format of assignments (e.g., written or spoken, individual or collective). As Chun and Plass (2000) note:

'Networked hypermedia environments not only present learners with information in various modes (visual, audio, and verbal/textual), but also require learners to engage in productive tasks and activities in a variety of modes, both synchronous and asynchronous methods of student collaboration, and they employ video, images, sound, and text for both the presentation and the negotiation of information' (pp. 152).

In addition, access to concordance software, online reference works (dictionaries and thesauruses), e-books, e-films, online language learning software programmes as well as an increasing number of online virtual libraries and conference areas for seminars and exhibitions such as those accommodated in Second Life (www.secondlife.com/) are readily available.

Apart from these choices in resource and communication modes, one of the main, unique benefits of a VLE for developing metacognitive linguistic capacities is the creation of a relevant database offering access to entire previous courses. As Deci and Ryan (2000) argue, one of the primary reasons why people initially perform extrinsicallymotivated behaviours is because these are:

'Prompted, modeled, or valued by significant others to whom they feel (or want to feel) attached or related' (p. 73).

Complete courses can be recorded online, and, in this way, new students, starting the same course, can navigate through these in their own time and participate in discussion with peers as well as previous students and tutors when and if they wish to.

Mayes (2002) states:

'The concept of tertiary courseware is to offer a new kind of resource which, instead of providing direct explanations of subject matter, tries to capture the essence of being an active member of a community of learners of that subject matter, providing access to the questions, comments and dialogues of previous learners' (p. 5).

Mayes (2002) terms this system 'dissemination'. In an experiment, the products of previous courses (written and spoken forums throughout; assignments and so on) were offered in addition to the standard online courseware. Two groups were compared, one with access and one without. Results demonstrated that the group with access showed much more enjoyment and satisfaction with the course. They also performed better.

'Dissemination' offers the opportunity for learners to relate to significant others and to participate in 'vicarious learning' (Bandura, 1986): learning solely through observing. Learners are encouraged to feel efficacious as they observe course activities that have already been modeled by significant others. They are encouraged to familiarise themselves with the kind of tasks and the standards of quality of these tasks on a course of study they are about to embark upon. Using Deci and Ryan's degrees of regulation, 'dissemination' fosters 'integrated regulation' (Deci et al. 1991, p. 330) as the activity to observe other courses peripherally, and learn vicariously, does not need to be an obligation or formal requirement of a course. In addition, there is no necessity for tokens, deadlines or evaluations at this initial stage. Therefore, vicarious learning can be solely recommended to students, to enable them to feel part of a larger community and to become familiar with the course they have decided to study.

'Dissemination', also strengthens the significance of the 'process of learning' rather than the 'product of learning'. Several different forums (i.e. whole class or group) can be set up at different stages of a course and relevant tasks uploaded and recorded. Students can then be asked to navigate through the stages of these previous courses and make significant commentaries, comparisons, evaluations or presentations. In this way the onus is, to a large extent, shifted to the process of development of the course, rather than solely focussing on the end-goal (passing the course successfully). This means a move away from an ends-oriented system of education (it has already been noted that concepts such as deadlines and rewards thwart integrated regulation).

\section{B. Developing Cognitive Linguistic Capacities}

Cognitive strategies for language learning are what might be termed learning the 'nuts and bolts' or 'mechanics' of a language (lexico-grammatical and phonological systems). Unlike metacognitive capacities, which may be carried out more or less independently, cognitive language growth is more often than not, embedded in the dynamics of social interaction and 'using English to learn it' (Howatt, 1984, p. 279; see also Breen and Candlin, 1980). The Soviet psychologist, Lev Vygotsky $(1962,1978)$ postulated that the social construct of a human's consciousness was primary. He stressed the interaction between internal and external forces, as do Deci and Ryan, but he exaggerated the primacy of the social aspect of our being. His premise is that consciousness is made up of two constructs - the intra-mental (similar to metacognition: individuals' abilities to make sense of the world and organise the multi-dimensional information that they are subjected to daily) and the inter-mental (the social). At the inter-mental level, consciousness is fundamentally social. Language was born through social interaction (i.e. hunting) and through communication it has grown. It is a shared, cultural artefact and thought (see also Sapir, 1921) requires language and undergoes many changes as it becomes language. It is thus, social in origin and cognitive language learning cannot and should not occur in isolation. Its basis should be communication and shared action.

Subsequently, through participation (first peripheral and then more complete) with peers and tutors, a learner is offered many opportunities for cognitive development. Language learning can be facilitated if learners are given opportunities to notice, learn, use and experiment with new language created through the connectivity of social 
interaction. As no two learners have the same lexicon, dialogues form a shared unit of language representing the Zone of Proximal Development (ZPD), defined by Vygotsky (1978) as:

'The distance between the actual developmental level as determined by independent problem solving and the level of potential development as determined through problem solving under adult guidance or in collaboration with more capable peers' (p. 86).

The ZPD is a natural social phenomenon. In first language learners an older peer such as a parent adopts 'caretaker' speech or 'motherese' (see Lightbown and Spada, 1993) for a child (commonly around the age of three) using language the child can understand, offering explanations of language used which might be slightly above the child's linguistic ceiling. Krashen (1982) calls this input (I) + 1, Bruner (1983) 'scaffolding'. In the same way, the ZPD is created by two predominant dynamics: interaction that takes place with more capable peers and that which occurs between relatively equal peers. In accordance with the Roman dictum 'Docendo discimus' ('we learn by teaching'). It is also said that the more able peers can also significantly benefit from this interaction.

An autonomy-supportive environment appears here as the individual's or group's freedom to choose the language they wish to analyze as it is created through written or spoken goal-oriented discourse and mediated through an online forum. Unlike the majority of standard classroom interaction, synchronous and asynchronous written or spoken dialogues can be recorded online, and a language database created and stored. Tudini (2005) argues that asynchronous computer-mediated written communication (ACMWC) thus promotes the 'noticing' of language errors and learner engagement in self-repair. In contrast to spontaneous and time-bound synchronous interaction in the classroom, studies have revealed that as students have time to reflect upon and formulate their thoughts before expressing them, this genre of communication produces a better quality of discourse. The loss of pressure associated with temporal experience (Kern, 1995; Ortega, 1997) reduces affective features (see Krashen, 1982), commonly understood as the areas involving feelings, emotions, mood and temperament (Chaplin, 1975), allowing students to become more absorbed in the tasks and less concerned with making linguistic errors, or deviances from the standard norm. Also, as learners have access to the database at all times, they are given the opportunity to spend time reflecting on their own language which has been created through meaningful social interaction and to correct or reformulate what they have said, with a view to improving it.

\section{The Role of the Online Facilitator in Promoting Autonomous Language Learning (Developing Community, Encouraging Discovery Learning and Offering Feedback)}

Although a great deal of language learning can take place independently, as argued above, some recent research to develop a group's awareness of the benefits of autonomous language learning collaboratively, (Ding, 2005), what Ding defines as 'inter-subjectivity collaborative autonomy', was disappointing. Ding invited international students at the University of Nottingham to work together through peer mentoring, collective language analysis and group writing online. He reports a lack of uptake as learners revealed disinclinations to identify as a group. Participants, who were all studying for the same undergraduate degree, offered in English as the medium of instruction, were also taking language courses with Ding as a support to their studies. It was found that competitivity from participants' major was transferred to their language course and subsequently, learners were particularly concerned about revealing their language weaknesses to each other.

The above-mentioned example might reveal the need for a tutor or facilitator in some instances. Although affective features can be significantly reduced through asynchronous communication, they may not be entirely removed. Thus, building a community of learners through online socialization tasks and discussions about the benefits of the online environment can help to instill learner motivation at the outset (see Brooke, 2012). Following this, activities analyzing the language that significant others from previous databases have compiled can help participants to become aware of the usefulness of the discourse mode. A skilled language tutor can provide students with language examples for analysis and:

'.. with activities which encourage students to think about samples of language, and to draw their own conclusions about how the language works'. (Willis, D \& J. 1996, p. 630)

Second language learning researchers and practioners (Ellis, R. 1992; Rutherford cited in Thornbury, 2001; Willis, J \& D, 1996) have termed this as consciousness-raising (C-R) and this is one way to guide learners on the road to autonomous learning with regard to cognitive strategies (see appendix 2 and 3). Ellis (cited in Willis, D \& J. 1996, p. 64) identifies three main goals for these grammar interpretation tasks: the first is to help learners identify meanings created by specific grammatical features; the second, to enhance input so that noticing a grammatical feature is induced; and the third is for learners to analyze the way they themselves use grammatical features. Using these aspects of language interpretation tasks, tutors are invited to challenge learners and to aid them to develop their cognitive strategies. Related to this is Holmberg's 'Theory and Practice of Distance Education' (1989, 2005), Laurillard's Conversational Model (1993) and more recently Ros, Solé and Truman's model (2007). It is suggested that tutors, rather than providing direct correction of errors, should leave clues through dialogue to enable learners to discover their errors. This helps to build autonomous, self initiating and self regulating reflection about language. Thornbury (2001) refers to this as 'intervention', and contrasts it with 'interference'. It should also be 'effectance' relevant (Ryan, Mims and Koestner, 1983, 738), signifying to a person whether she is competent with the target language and if not, how to become so. Throughout, a concentric approach is recommended incorporating language already discussed whilst at the same time 
introducing new language. This also means that meaningful feedback is given in its social and linguistic context and it should be delivered in an informal, friendly way ensuring a maximum of learner participation.

SDT argues that giving feedback to learners is essential. This has already been cited in this paper (p. 10). For the promotion of an autonomy-supportive environment:

'A person needs to be able to get some sense of how well he or she is doing at the activity to remain intrinsically interested'. (Ryan, Mims and Koestner, 1983, p. 738)

Asynchronous spoken, and particularly written $\mathrm{CMC}$, is an optimal environment for giving feedback. The tutor, as well as sharing feedback with all participants at once, can communicate with individuals privately at any time, and in any time (real time, asynchronous time) during periods of interaction. If the tutor feels that open feedback to an individual might have affective repercussions, this can therefore be avoided. This means that the tutor is able to perform as both facilitator and counsellor providing psycho-social support.

\section{CONCLUSION}

This paper has argued that VLEs, such as Blackboard and Moodle, offer new possibilities for an optimal autonomysupportive environment for two-way language learning at a distance. They offer a range of mediums for communication and knowledge retrieval; they facilitate both vicarious learning and learning through participatory interaction; they give opportunities for deeper thinking via the 'time gap' or loss of temporal experience, in asynchronous spoken and written communication. Through interaction, tutors can create consciousness-raising language activities to challenge participants. In addition, there is scope for learners to acquire new language from their peers within the dynamics of the ZPD. Peer and tutor feedback need not be shared with the whole class, but can be given privately to individuals, reducing affective factors and personalising commentary. Finally, it has been demonstrated that a focus on process rather than product can also be facilitated through the creation and review of forums; the interaction recorded on these by participants (past or present) can be referred to and compared. By focussing on process and analysing the language used in their own database, students can also be guided to reflect on their own language in use (spoken or written). This type of language learning activity, it might be suggested, (see Nakamura and Csikszentmihalyi, 2002) could lead more readily to the facilitation of a state of 'flow' or 'autotelic' (auto: self; telos: goal) activity, a concept closely related to autonomy and intrinsic motivation, as they build interest and energise learning. Goleman (1995) states:

'Flow represents perhaps the ultimate in harnessing the emotions in the service of performance and learning. In flow the emotions are not just contained and channelled, but positive, energised and aligned with the task at hand' (p. 91).

This is an optimal state for effective learning and, although using VLEs for language learning remains at an early stage of development, it is evident that these are potentially very effective environments for facilitating autonomous language learning. It is hoped therefore, that future research in this field can help to explore these possibilities.

\section{APPENDIX 1}

(Adapted from Richards and Rogers, 2001, pp. 64-65)

In a typical audiolingual lesson, the following procedures would be observed:

1. Students first hear a model dialogue (either read by the teacher or on tape) containing the key structures that are the focus of the lesson. They repeat each line of the dialogue, individually and in chorus. The teacher pays attention to pronunciation, intonation and fluency. Correction of mistakes of pronunciation or grammar is direct and immediate. The dialogue is memorised gradually line by line. A line may be broken down into several phases if necessary. The dialogue is read aloud in chorus, one half saying one speaker's part and the other half responding. The students do not consult their book throughout this phase.

2. The dialogue is adapted to the students' interest or situation, through changing certain key words or phrases. This is acted out by the students.

3. Certain key structures from the dialogue are selected and used as the basis for pattern drills of some kinds. These are first practised in chorus and then individually. Some grammatical explanation may be offered at this point, but this is kept to an absolute minimum.

4. The students may refer to their text books, and follow up reading, writing or vocabulary activities based on the dialogue may be introduced. At the beginning level, writing is purely imitative and consists of little more than only copying sentences that have been practised. As proficiency increases, students may write out variations of structural items they have practised or write short compositions on given topics with the help of framing questions, which will guide their use of the language.

5. Follow up activities may take place in the language laboratory, where further dialogue and drill work is carried out.

\section{APPENDIX 2}

Typical content of consciousness-raising activities for learners of a second or foreign language (adapted from Willis, 1996, p. 70). 


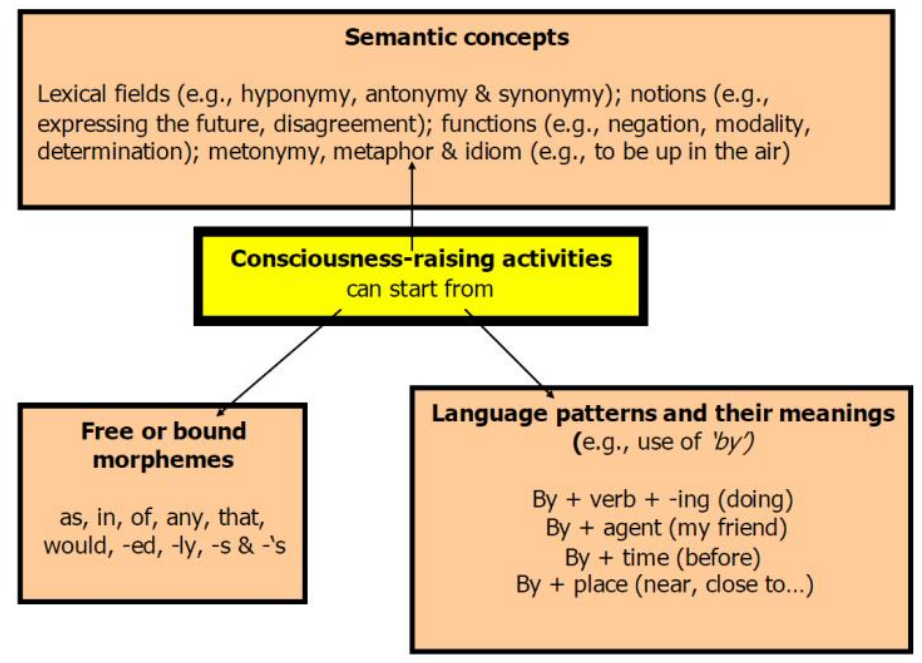

\section{APPENDIX 3}

\section{Example of a simple consciousness-raising activity for the use of 'would' in English}

Here are some sentences with 'would' that students should have seen in previous lessons. Students are asked to find sentences in which would:

1. ... is used as a conditional.

2. ... is the past tense of will.

3. ... means 'used to'.

With the remaining sentences, what are the uses of 'would'?

a) If you were designing a poster, which two would you use?

b) Would you like to ask anything about it?

c) Yes, I would agree with that.

d) We would always have band practice on Friday nights.

e) He looked at the painting and decided he would hang it in the sitting room.

answers
d $=1$
$\mathrm{e}=2$
$\mathrm{~b}=$ an offer
$\mathrm{c}=\mathrm{a}$ (semi) fixed expression in which 'would' acts as a marker of
politeness

\section{REFERENCES}

[1] Amabile, T. M., DeJong, W., and Lepper, M. R., (1976). Effects of externally imposed deadlines on subsequent intrinsic motivation. Journal of Personality and Social Psychology, vol. 34, pp. 92-98.

[2] Aoki, N. (1999). 'Affect and the roles of teachers in the development of learner autonomy', in J Arnold (Ed.), Affect in language learning, Cambridge University Press, Cambridge.

[3] Bandura, A. (1986). Social Foundations of Thought and Action. Englewood Cliffs, Prentice-Hall, NJ.

[4] Bangeni and Nel, (2007). Chapter 6 in Distance Education and Languages Holmberg, B, Shelley, M, White, C (eds.), New Perspectives on Language and Education.

[5] Bates, A. W. (1995). Technology, Open Learning and Distance Education, Routledge, London.

[6] Benson, P. (2000). 'Autonomy as a learners' and teachers' right', in B Sinclair, et al. (eds.), Learner Autonomy, Teacher Autonomy: Future Directions, Longman, London, pp. 111-117.

[7] Benson, P. (2001). Teaching and researching autonomy in Language learning. Pearson Education Limited, Harlow.

[8] Benson, P. and Toogood, S. (eds.), (2001). Learner Autonomy 7: Challenges to Research and Practice, Authentik, Dublin.

[9] Birdsong, D. (1989). Metalinguistic performance and interlinguistic competence. Springer-Verlag. Berlin.

[10] Breen, M, P. and Candlin, C, N. (1980). 'The essentials of a communicative curriculum in language teaching', Journal of Applied Linguistics, vol. 1, no. 2, pp. 89-112.

[11] Brooke, M. (2012). Enhancing Pre-Service Teacher Training: The Construction and Application of a Model for Developing Teacher Reflective Practice Online. Open Journal of Modern Linguistics 2012. Vol.2, No.4, pp. 180-188. Published Online December 2012 in SciRes (http://www.SciRP.org/journal/ojml). 
[12] Brooke. M. (2012). A Series of Case Studies Exploring How to Develop and Maintain A Community of Pre-Service Trainee ESL Teachers on Field Experience Practicum in Hong Kong. International Journal of Applied Science and Technology (IJAST). Vol. 2 No. 10; pp. 42-52. Published Online, December 2012.

[13] Bruner, J (1983). Child's Talk: Learning to Use Language. Norton, New York.

[14] Chomsky, N. (1966). Linguistic theory. Reprinted in J.P.B. Allen and P. Van Buren (eds.), Chomsky: Selected Readings. Oxford University Press, Oxford, pp. 152-159.

[15] Chun, D. C. and Plass, J.L. (2000). Networked Multimedia Environments for Second Language Acquisition. In: M. Warschauer and R. Kern, Cambridge Applied Linguistics Series, Cambridge University Press, Cambridge, pp. 151-170.

[16] Clarke, F. D. (1991). The Negotiated Syllabus: What is it and How is it Likely to Work? in Applied Linguistics, Oxford University Press, Oxford, vol. 12, no. 1, pp. 13-28.

[17] Conlon, T. (2000). Visions of Change: information technology, education and postmodernism, British Journal of Educational Technology, vol. 31, no. 2, pp. 109-116.

[18] Csikszentmihalyi, M. (1990). Flow: The Psychology of Optimal Experience. Harper and Row, New York.

[19] Cuban, L., Kirkpatrick, H., \& Peck, C. (2001). High Access and Low Use of Technologies in High School Classrooms: Explaining an Apparent Paradox, American Educational Research Journal, vol. 38, no. 4, pp. 813-834.

[20] Dam, L. (1995). Learner autonomy 3: from theory to classroom practice. Authentik, Dublin.

[21] Deci, E. L. (1971). Effects of externally mediated rewards on intrinsic motivation. Journal of Personality and Social Psychology, vol. 18, pp. 105-115.

[22] Deci, E. L., Betley, G., Kahle, J., Abrams, L., and Porac, J. (1981). When trying to win: Competition and intrinsic motivation. Personality and Social Psychology Bulletin, vol. 7, no. 1, pp. 79-83.

[23] Deci, E. L., Koestner, R., and Ryan, R. M. (1999). A meta-analytic review of experiments examining the effects of extrinsic rewards on intrinsic motivation. Psychological Bulletin, vol. 125, pp. 627-668.

[24] Deci, E. L. and Ryan, R. M. (1985). Intrinsic motivation and self determination in human behaviour. Plenum Press, New York.

[25] Deci, E. L. and Ryan, R. M. (1991). A motivational approach to self: Integration in personality. In Dienstbier, R.A. (Ed.), Perspectives on motivation. Nebraska Symposium on Motivation, 1990, vol 38, Lincoln: University of Nebraska Press, pp. $237-$ 88.

[26] Deci, E. L. and Ryan, R. M. (2000). The "what" and "why" of goal pursuits: Human needs and the self-determination of behaviour. Psychological Enquiry, vol. 11, no. 4, pp. 227-268.

[27] Deci, E. L. and Ryan, R. M. (2000). Intrinsic and Extrinsic Motivations: Classic Definitions New Direction, Contemporary Educational Psychology vol. 25, pp. 54-67.

[28] DeCharms, R. (1968). Personal causation. Academic Press, New York.

[29] Dewey, J. (1938). Experience and education. Collier Books, London.

[30] Ding in Hauck, M. and Hampel, R. (2005) The challenge of implementing online tuition in distance language courses: Task design and tutor role, in Holmberg, B., Shelley, M. and White, C. (eds.) Distance Education and Languages: Evolution and Change, New Perspectives on Language and Education series, Clevedon: Multilingual Matters: 258-277.

[31] Ellis, R. (1992). Second Language Acquisition and Language Pedagogy, Multilingual Matters.

[32] Evans, T. and Nation, D. (1992). Theorising Open and Distance Education; Open Learning, June 1992, pp. 3-13.

[33] Fabos, B. and Young, M.D. (1999). Telecommunication in the Classroom: Rhetoric versus Reality, Review of Educational Research, vol. 69, no. 3, pp. 217-259.

[34] Felix, U. (2002). The web as vehicle for constructivist approaches in language teaching. ReCALL, vol. 14, no. 1, pp. 2-15.

[35] Fries, C. C. (1945). Teaching and Learning English as a Foreign Language, Ann Arbor: University of Michigan Press.

[36] Fries. C. C. and A. C. Fries. (1961). Foundations for English Teaching. Kenkyusha, Tokyo.

[37] Goleman, D. P. (1995). Emotional Intelligence: Why It Can Matter More Than IQ for Character, Health and Lifelong Achievement. Bantam Books, New York.

[38] Goleman, D. (2006). Social Intelligence: The New Science of Social Relationships (2006) Bantam Books. NY.

[39] Grolnick, W. S., \& Ryan, R. M. (1987). Autonomy in Children's learning: An experimental and individual difference investigation. Journal of Personality and Social Psychology, vol. 52, no. 5, pp. 890-898.

[40] Harlow H. F. (1950). Analysis of discrimination learning by monkeys. Journal of Experimental Psychology vol. 40, pp. $26-39$.

[41] Hauck, M. and R. Hampel. (2005). The challenge of implementing online tuition in distance language courses: Task design and tutor role in Holmberg, B., Shelley, M. and White, C. (eds.) Distance Education and Languages: Evolution and Change, New Perspectives on Language and Education series, Clevedon: Multilingual Matters, 258-277.

[42] Hedge, T. (2000). Teaching and Learning in the language classroom, Oxford University Press, Oxford.

[43] Holec, H. (1981). Autonomy and Foreign Language Learning, Pergamon, London.

[44] Holmberg, B. (1989). Theory and Practice of Distance Education. Routledge, New York.

[45] Howatt, A.P.R. (1984). A History of English Language Teaching (Chapter 3) Oxford University Press, Oxford.

[46] Hunt, E. B. (1971). What kind of computer is man? Cognitive Psychology, vol. 2, pp. 57-98.

[47] Kern, R. G. (1995). Restructuring classroom interaction with networked computers: Effects on quantity and characteristics of language production. The Modern Language Journal, vol. 79, no. 4, pp. 457-475.

[48] Krashen, S. D. (1982) Principles and Practice in Second Language Acquisition, Pergamon Press, Oxford.

[49] Laurillard, D. (1993). Rethinking University Teaching: a framework for the effective use of educational technology, Routledge, London.

[50] Lepper, M. R., Greene, D., and Nisbett, R. E. (1973). Undermining children's intrinsic interest with extrinsic rewards: A test of the "over-justification" hypothesis. Journal of Personality and Social Psychology, vol. 28, pp. 129-137.

[51] Lightbown, P. and Spada, N. (1993). How Languages are Learned Oxford University Press, Oxford.

[52] Little, D. (1991). Learner autonomy 1: Definitions, issues and problems, Authentik, Dublin.

[53] Mayes, J. T. (2002). The technology of learning in a social world. In R. Harrison, F., Reeve, A. Hanson, J., Clarke (eds.), Supporting Lifelong Learning, vol. 1: Perspectives on Learning, Routledge, London. 
[54] Milton, J. (2007). http://www.cs.ust.hk/gong. Chapter 14 in Distance Education and Languages Holmberg, B, Shelley, M, White, C (eds.), New Perspectives on Language and Education.

[55] Moore, M. G. (1993). Theory of transactional distance. In D. Keegan (Ed.), Theoretical principles of distance education Routledge, New York, pp. 22-38.

[56] Murphy in Hauck, M. and R. Hampel. (2005). The challenge of implementing online tuition in distance language courses: Task design and tutor role in Holmberg, B., Shelley, M. and White, C. (eds.), Distance Education and Languages: Evolution and Change, New Perspectives on Language and Education series, Clevedon: Multilingual Matters, 258-277.

[57] Nakamura, J and Csikszentmihalyi, M. (2002). Handbook of Positive Psychology. Snyder \& Lopez (eds.,), Oxford University Press, Oxford.

[58] Nuttin, J. R. (1973). Pleasure and reward in human motivation and learning. In D. E. Berlyne \& K. B. Madsen (eds.), Pleasure, reward, preference: Their nature, determinants, and role in behavior, Academic, New York, pp. 243-273.

[59] O'Malley, J. M; Chamot, A. U; Stewner - Manzanares, Gloria; Rocco P., and L. Kupper. (1985). "Learning Strategy Applications with Students of English as a Second Language" in TESOL Quarterly vol. 19: pp. 557-584.

[60] Ortega, L. (1997). Processes and outcomes in networked classroom interactions: Defining the research agenda for L2 computer-assisted classroom discussion. Language Learning \& Technology, vol. 1, no. 1, pp. 82-93. (Retrieved November 29, 2005, from http://lt.msu.edu/vol1num1/ortega/default.html).

[61] Richards, J. C., and Rogers, T. S. (2001). Approaches and Methods in Language Teaching. Cambridge University Press, Cambridge.

[62] Reinders, H. (2000). 'Do it yourself? A learner's Perspective on Learner Autonomy and Self-Access Language Learning in an English Proficiency Programme' MA dissertation, University of Netherlands.

[63] Riley, P. (1986). 'Who's who in self-access? TESOL France News, vol. 6, no. 2, pp.23-35.

[64] Riley, P. (1997). 'The Guru and the conjurer: aspects of counselling for self-access', in P Benson \& P Voller (eds.), Autonomy \&Independence in Language Learning, Addison Wesley Longman Limited, London.

[65] Ros, Solé and Truman, (2007). Chapter 5 in Distance Education and Languages Holmberg, B, Shelley, M, White, C (eds.), New Perspectives on Language and Education.

[66] Ryan, R. M., Mims, V., and Koestner, R. (1983). Relation of reward contingency and interpersonal context to intrinsic motivation: A review and test using cognitive evaluation theory. Journal of Personality and Social Psychology, vol. 45, pp. 736-750.

[67] Sapir, E. (1921). Language: An introduction to the study of speech. New York: Harcourt, Brace and company.

[68] Schank, R. C., and Jona, M. (1991). 'Empowering the student: New perspectives on the design of teaching systems', Journal of the learning sciences, vol. 1, no. 1, pp. 7-35.

[69] Skinner, B. F. (1953). Science and human behaviour. Macmillan, New York.

[70] Steeples et al. (2007) in Distance Education and Languages Holmberg, B; Shelley, M; White, C. (eds.), New Perspectives on Language and Education.

[71] Sumner, J. (2000). Serving the System: a critical history of distance education, Open Learning, vol. 15, no. 3, pp. $267-285$.

[72] Thornbury, S. (2001). Uncovering Grammar. Macmillan Heinemann.

[73] Thorndike, E. (1913). Educational Psychology: The Psychology of Learning. Teachers College Press, New York.

[74] Tudini in Hauck, M. and R. Hampel (2005). The challenge of implementing online tuition in distance language courses: Task design and tutor role in Holmberg, B., Shelley, M. and White, C. (eds.) Distance Education and Languages: Evolution and Change, New Perspectives on Language and Education series, Clevedon: Multilingual Matters, 258-277.

[75] Vallerand, R. J., and Bissonnette, R. (1992). Intrinsic, extrinsic, and amotivational styles as predictors of behaviour: A prospective study. Journal of Personality, vol. 60, pp. 599-620.

[76] Van Lier, L (1996). Interaction in the Language Curriculum, Awareness, autonomy and authenticity, Longman.

[77] Voller, P. (1997). 'Does the teacher have a role in autonomous learning?' in P Benson \& P Voller (eds.), Autonomy and Independence in Language Learning, Addison Wesley Longman Limited, London.

[78] Vygotsky, L. S. (1962). Thought and Language (new edition. A. Kozulin). Harvard University Press, Cambridge, MA.

[79] Vygotsky, L. S. (1978). Mind in Society: The Development of Higher Psychological Processes. Harvard University Press, Cambridge, MA.

[80] Watson, D. M. (2001). Pedagogy before Technology: Re-thinking the Relationship between ICT and Teaching Education and Information Technologies vol. 6, no. 4, pp. 251-266.

[81] Willis, J \& D. (1996). Challenge and Change in Language Teaching. Macmillan Heinemann.

Mark Brooke, BA (hons) in English and Political Science; MA in Applied Linguisitcs; Diplôme Supérieure de Français Langue Etrangère; Trinity Licentiate Diploma in TESOL; M.Sc in Teaching English for Specific Purposes

Mark is currently working as a Senior Teaching Fellow at the Hong Kong Institute of Education. Before this, he worked at the English Language Centre of City University, Hong Kong. Prior to moving to Hong Kong, Mark worked in TESOL in mainland China, Italy, the UK and France. Mark is completing an EdD with Durham University, UK. He has published on various research subjects related to TESOL including teaching language through online language learning communities; discourse analysis; preservice language teacher training; using corpora for discovery language learning; course design; and qualitative research paradigms, in particular action research. 